\title{
Epstein-Barr Viral Status
}

National Cancer Institute

\section{Source}

National Cancer Institute. Epstein-Barr Viral Status. NCI Thesaurus. Code C157444.

A viral load assay of the Epstein-Barr virus which may be an indicator of disease status. 